\title{
Behavioural changes of the business parties in the tourist sector after the implementation of the measures for overcoming the Covid-19 crisis
}

\author{
Zlatka Grigorova ${ }^{1}$, and Yulia Dzhabarova ${ }^{2 *}$ \\ ${ }^{1}$ University of Agrobusiness and Rural Development, Plovdiv, Bulgaria \\ ${ }^{2}$ Plovdiv University Paisii Hilendarski, Plovdiv, Bulgaria
}

\begin{abstract}
The harmful consequences of Covid-19 mostly influenced the Tourist sector worldwide. The negative trends shaped the fearful reality for all related businesses and involved parties and let them face the challenge to overcome this cruel environment of existence and streamline their future survival and development. To prevent the companies from the environmental threats, and to support their recovery and future stable existence, many different measures at national and regional level were taken. The paper aims at clarifying the influence and efficiency of the carried-out measures in the Tourist sector. The applied methodology is based on the comparative analysis. For this purpose, an online research was conducted in two different periods, and the data was registered through questionnaires containing three structured thematic blocks. The sample consists of 73 representatives, presented by different parties from the Tourist sector in the Plovdiv region. The survey was conducted in the period of April $2020-$ April 2021. The provided conclusions and recommendations could serve all institutions at national and regional level, as well as business organizations in their policies. The policy makers and the policy recipients could both benefit from the results of the study in order to reply adequately to the challenges of the surrounding environment and consumer requirements, and thus, to be able to adapt their business and marketing strategies.
\end{abstract}

\section{Introducion}

The harmful effects of Covid-19 have had extremely strong impact on the global tourism sector. Negative trends have shaped the decisive reality for all tourism-related industries. They were forced to face the challenge of overcoming the crisis and streamlining their behavior in order to survive and develop.

Tourism has emerged as one of the most affected economic sectors, with a global decline of more than $73 \%$ in international travel in 2020, as data of the World Tourism Organization (UNWTO) shows that all destinations around the world have complied with travel restrictions, and some continue to this day. (Fig.1)

The Covid-19 pandemic has dramatically changed people's lives, threatening their health, disrupting economic activity, prosperity and jobs. Today, Covid-19 is a health catastrophe

* Corresponding author: j_jabarova@yahoo.com 
that leads to a global economic crisis, to a social crisis, to deepening inequalities and has the potential to dramatically change tourist behavior for more than one season, a year or two.

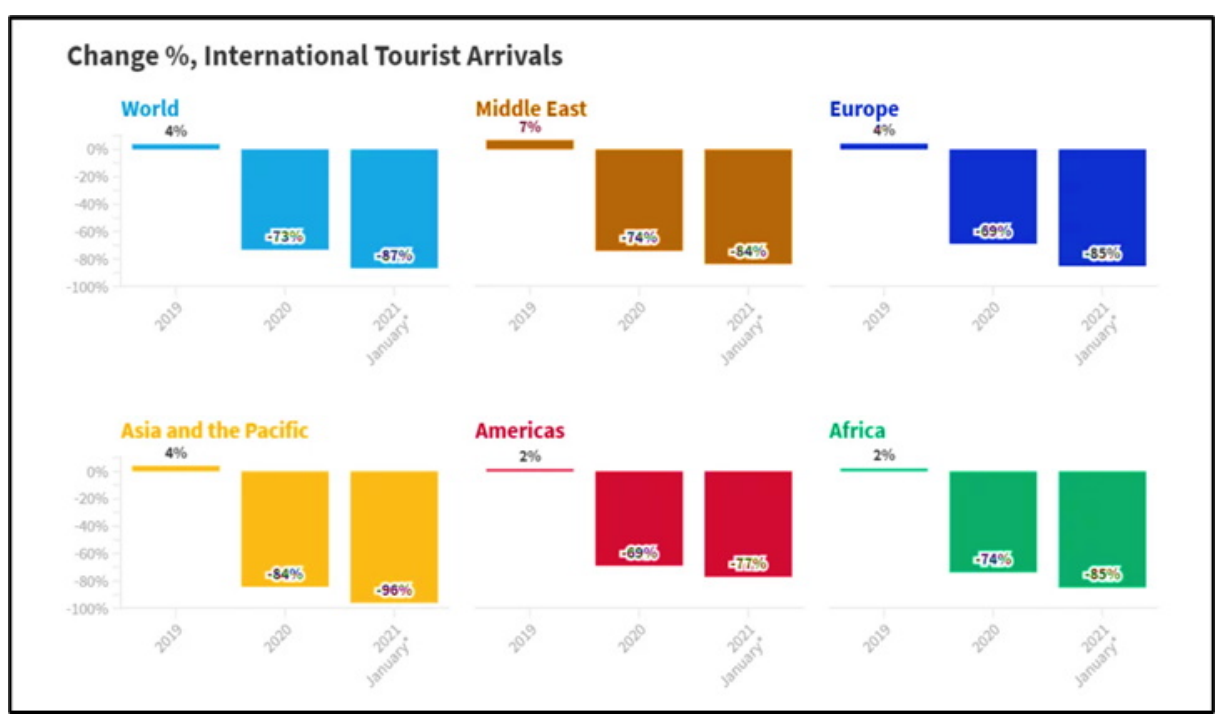

Fig. 1. International travel in 2019-2021, UNWTO (https://www.unwto.org/news/tourist-numbersdown-83-but-confidence-slowly-rising -10.06.2021)

The effects of Covid-19 are not limited to health risks. It leads to an economic recession, to an increase in unemployment and a decrease in income, respectively to a limitation of the potential demand for a tourist product. And if today tourism is among the first sectors affected, it will probably be among the last to fully recover because of the priority of other needs (food, education, security).

Estimates of consequences and recovery are difficult in the face of uncertainty, with longer-term ones depending on factors such as:

- duration of the crisis;

- public support policies;

- behavior of tourists (loss of interest or increased interest in tourist travel, confidence in attracting tourists to destinations, etc.).

These external factors are complemented by a number of situational factors in the destinations, such as: degree of dependence on tourism, adequacy of tourism management at different levels, ability to adapt to changing tourist behavior.

Globally, we recognize the following effects of the pandemic:

- Rapid economic downturn affecting both tourism-related enterprises and the economy as a whole (global stagnation, staff reductions, rising unemployment and declining incomes), declining tourism demand, which is a vicious circle that is difficult to break;

- Restriction of travel, which leads to reduced tourist demand and tourist activity;

- Social distancing and reduced trust between people (discrimination, violence, waves of immigrants);

- Avalanche of domestic and international disputes that sharply worsen trade relations, limit supplies, and shrink the market.

Following the first registered cases of Covid-19, a state of emergency was imposed in Bulgaria in March 2020. A number of strict measures were imposed aimed at limiting the spread of the virus, and by order of the Minister of Health the activity of all facilities for food and accommodation services was paused, as well as visits to cultural sites. Virtually the entire tourism sector has been "quarantined". 
In 2020-2021, in order to preserve the tourism business and protect the economic entities in the tourism market from bankruptcy, as well as to speed up the recovery of the sector after the pandemic, the national and local authorities developed a number of policies and introduced specific measures through a series of legislative changes aimed at providing and/or redirecting financial resources, including such ones from operational programs. Public authorities have tried to coordinate the development of measures to ensure the health and safety of travelers in accommodation, catering, tourist attractions and other sites visited by tourists [1].

What are the applied policies and measures, and how did they affect the business?

The aim of the present study is to clarify the impact and efficiency of the anti-crisis measures introduced by the state and local authorities to the tourism sector in Plovdiv, and to reveal the business's attitudes towards recovery.

\section{Materials and methods}

In the present article, a comparative analysis is performed by applying descriptive statistics. The data was registered as a result of two independent empirical studies, respectively: the first was carried out in April 2020 and the second - in April 2021, with the aim of tracking the status and changes in the activities of various institutions in the industry as a result of the measures introduced to deal with the crisis.

The method of the survey was applied, and the inquiry was conducted online. The questions were 19 in total, structured in three thematic blocks: A) general issues related to the organization, incl. type of activity, term of implementing the activity, staff, financial results, etc.; B) awareness of the measures implemented to overcome the pandemic of Covid19 , respectively at national and local level, as well as the efficiency of their implementation;

C) future expectations regarding the state and activity of the organization.

The respondents are representatives of the following main groups, involved in the tourism sector: private companies, public sector organizations, non-governmental organizations. The study was conducted on the territory of Plovdiv with the assistance of "Tourism Council Plovdiv". Seventy-three tourist and/or tourism-related companies and institutions responded to the survey, of which over $70 \%$ were directly engaged in tourism. The results of the study in the first stage were published on the website of the association [2] and were communicated in the public media to the mass audience.

\section{Results}

Results based on a data of the National Statistical Institute on the direct effects of Covid-19 on tourism for 2020 and the first half of 2021 presents a negative trend that can be traced at all levels. There is a dramatic decline in tourist demand compared to the same period last year, according to the main indicators: employment in the field of tourism, number of nights and overnight stays, trips of Bulgarian citizens abroad and of foreigners in Bulgaria, number and capacity of accommodation places, realized nights, etc. [3] In the statistics regarding the international tourism in Bulgaria for 2020, the Ministry of Tourism reports for the period January - December a total number of 2,687,709 tourist visits by foreigners, as the decrease compared to the period January - December 2019 is $71.1 \%$ [4]. Eurostat's analysis of accommodation activities in the European Union for 2020 compared to the same period in 2019 shows that Bulgaria is not an exception in terms of the impact of the pandemic on tourism, as in terms of the volume of effective tourism demand and the dynamics of demand in domestic tourism [5]. 
Destination Plovdiv was a recognizable tourist destination for the European travelers until the pandemic, and a desirable business environment in the field of tourism. The title "European Capital of Culture 2019" promotes the cultural wealth of the destination and generates significant cultural, social, and economic benefits [6]. The emphasis of future development was then placed on unlocking the local potential through the development of diverse and modern forms of tourism [7].

With the change within the Covid-situation at national and regional level, a number of policies and measures have been taken to preserve the business, but what is their effect on the sector remains to be seen.

The results of the conducted survey with representatives of the tourism sector present the current situation of the tourism industry in the Plovdiv region during the state of emergency (April 2020 and April 2021), as well as the vision of the industry for trends of recovery and restart of the sector.

A) General issues:

According to the organization and type of activity, the respondents are grouped in the following categories: $77.3 \%$ of the business, 13.5 public authorities and 9.2 others, as $45.1 \%$ are hoteliers; $15.7 \%$ of tour operators; $7.8 \%$ restauranteurs; $5.9 \%$ are in the field of education; $3.9 \%$ of guides and others directly or indirectly related to tourism - Fig.2.

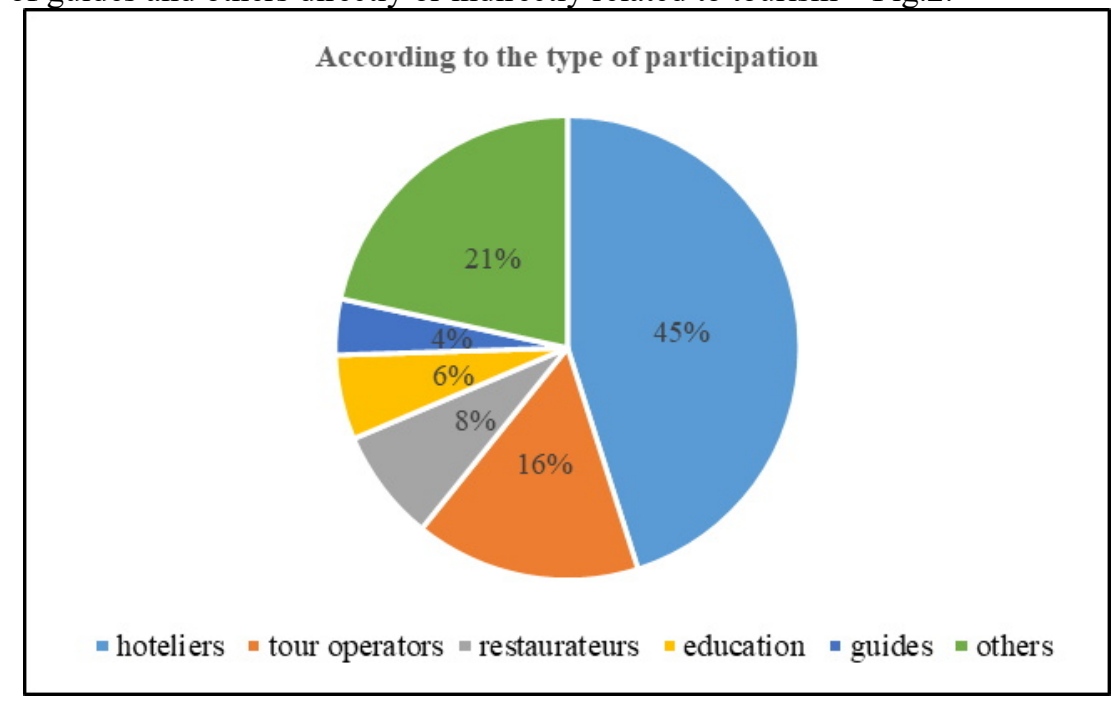

Fig. 2. According to the organization and type of activity

According to the duration of activity on the tourist market - mainly they are companies established on the tourist market that have been operating for over 20 years or between 10 and 20 years. The tourism sector has its well-established economic positions in Plovdiv, and its experience is of paramount importance for adequate work during emergencies and crises - in period 2 the companies over 10 years are $77.3 \%$ of respondents - Fig.3. 


\section{According to the duration of intensive activity on the tourist} market

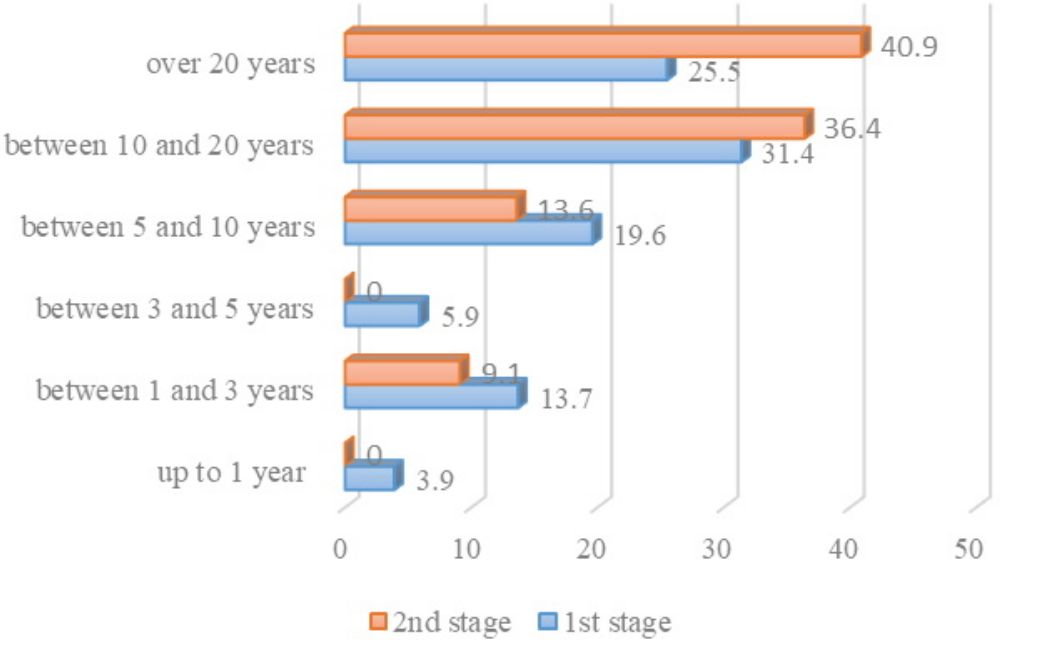

Fig. 3. According to the duration of activity on the tourist market

The Covid-19 pandemic has massively a negative impact on the tourism industry with $92.2 \%$ of respondents in period 1 and $81.8 \%$ in period 2 , but only $4 \%$ closed in period 1 , while in period $236.4 \%$ reduced the workload by more than $50 \%$ and $27.3 \%$ completely stopped it. To the question: What changes did you have to make to your staff as a result of the Covid-19 pandemic (with the possibility of several answers), there are clear problems such as: mass layoffs, unpaid leave, reduced working hours and others. (Fig.4)

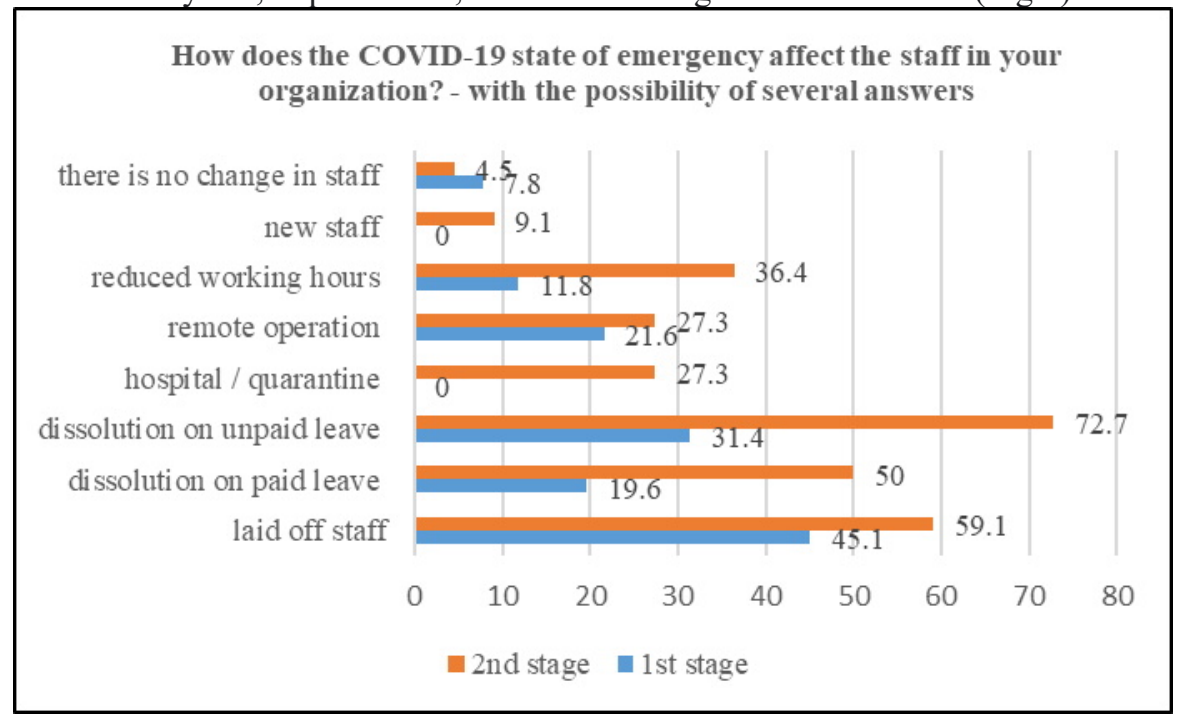

Fig 4. Consequences of the emergency on staff

Despite the serious difficulties: $62.7 \%$ suspended their activities in period 1 and $27.3 \%$ in period 2 , as well as $2 \%$ permanently ceased their activities, there is still a desire to retain staff and jobs in the sector. (Fig.5). 


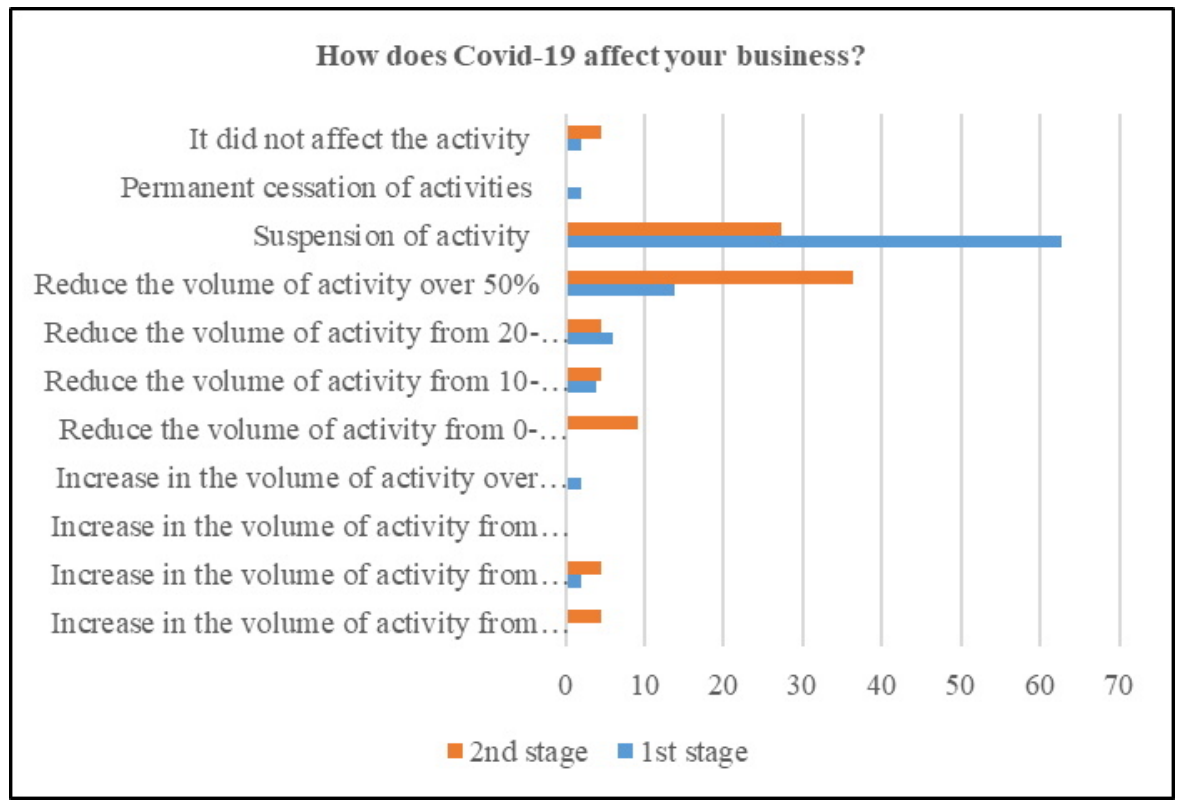

Fig. 5. The effect of Covid-19 on activity

In the adaptation of the business to the current situation, there is a tendency to increase the use of online channels for dissemination of information and business meetings, as $39.2 \%$ have started to use more social media; $33.3 \%$ update their sites; $11.8 \%$ managed to adapt their business to using an online ordering site; but $45.5 \%$ cannot adapt to digitalization. This corresponds to the fact that $59.1 \%$ of companies have laid off staff or do not work.

B) Awareness of the measures implemented to overcome the Covid-19 pandemic at national and local level:

In order to preserve the tourism business and prevent mass bankruptcies [8], as well as to speed up the recovery of the sector after the pandemic, the national and local authorities have implemented policies and measures to ensure the health and safety of travelers in accommodation [9], catering and entertainment establishments. tourist attractions and other sites visited by tourists [10].

The study related to the industry awareness of the implemented measures for overcoming the pandemic of Covid-19 at national level, as well as the effectiveness of their implementation, covers the following measures:

- Support for small businesses with a turnover of over BGN 500,000 to overcome the economic consequences of the Covid-19 pandemic [11]

- Providing grants to persons performing tour operator and travel agency activities to compensate for losses resulting from the Covid-19 epidemic [12]

- Support to micro and small enterprises to overcome the economic consequences of the Covid-19 pandemic (measure 3/10) [13]

- Support for medium-sized enterprises to overcome the economic consequences of the pandemic Covid-19 - OPIC [14]

- Measure 60/40 [15]

- Measure "Employment for you“ [16]

- BDB program for portfolio guarantees in support of the liquidity of micro, small and medium enterprises (SMEs) affected by the emergency situation and the epidemic of Covid19 [17]

- Crisis recovery loans Covid-19 (by the Fund of funds) [18] 
- Microloans for self-employed persons and small start-ups (by the Fund of funds) [19]

- Portfolio guarantees to support the liquidity of SMEs (European Investment Fund) [20]

- Microloans for self-employed persons and small start-ups [21]

$87 \%$ of the respondents are fully or largely familiar with the measures, but $2 / 3$ believe that they have not fully or completely supported them - Fig.6 and Fig.7.

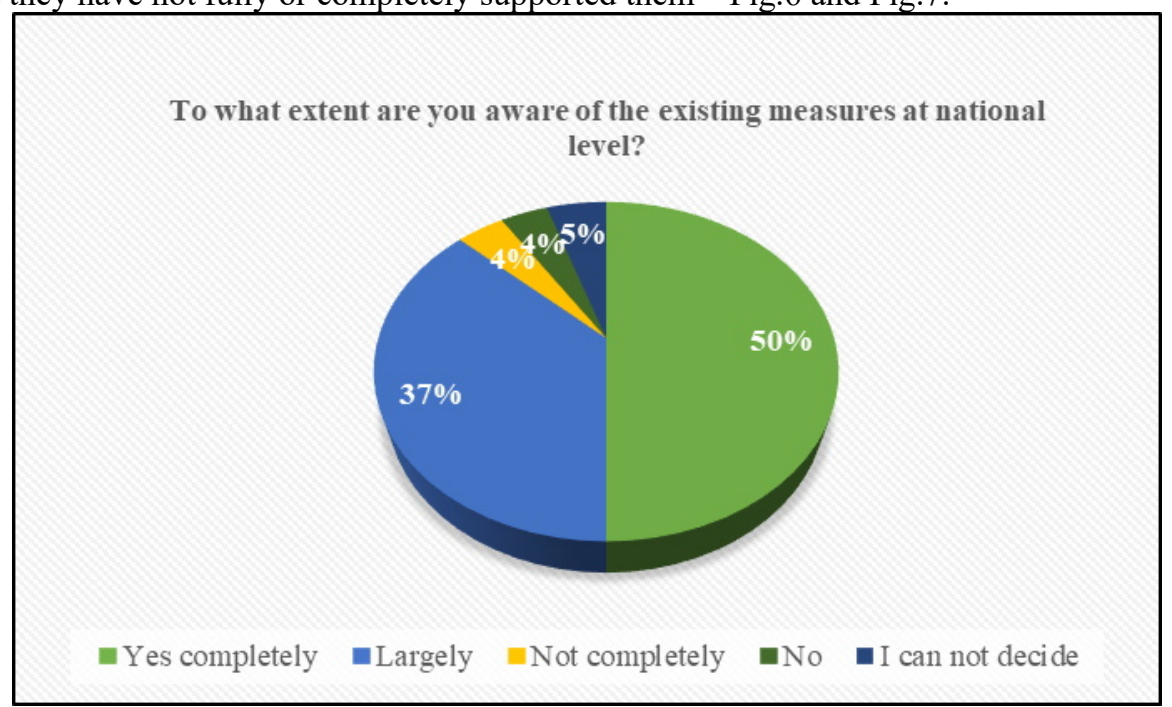

Fig. 6. Level of awareness of the measures at national level

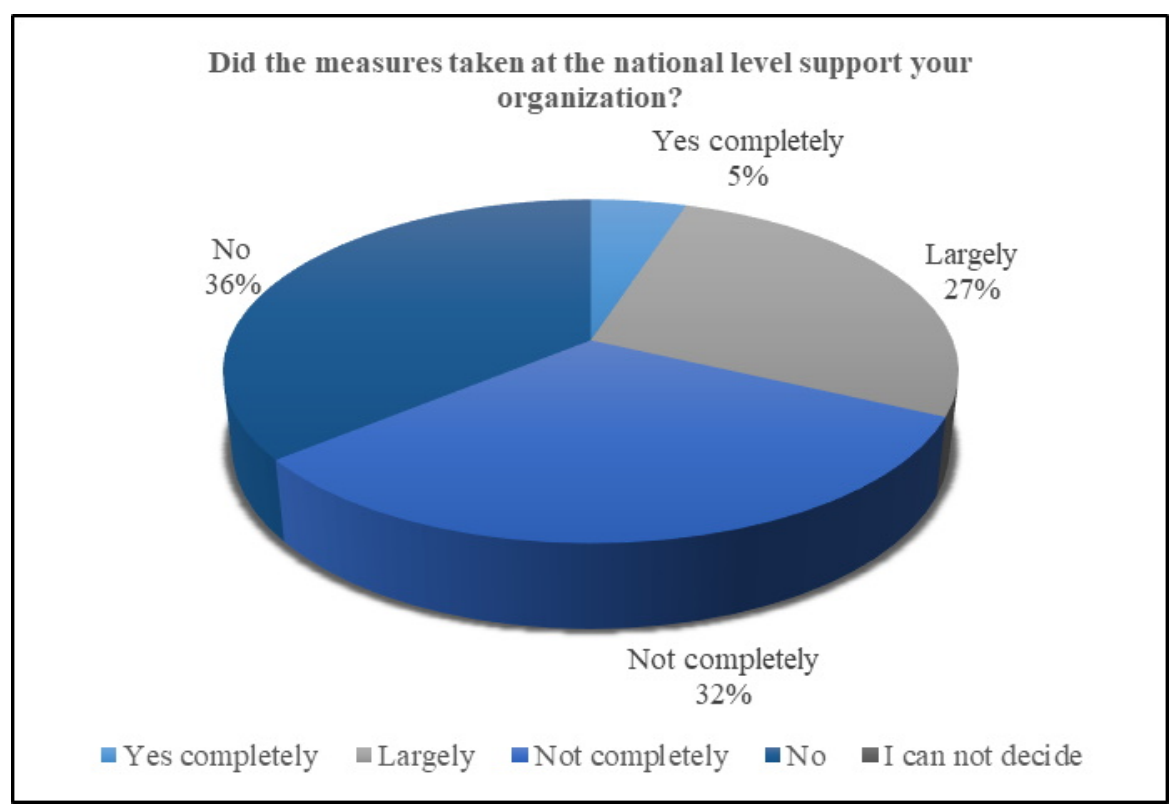

Fig. 7. Degree of influence of the measures at national level

The attitude of the respondents to measure $60 / 40$ is particularly indicative $-74.6 \%$ are negative, $19.6 \%$ intend to take advantage, and $5.9 \%$ indicate that they have already taken advantage. One third of the respondents answered that these measures do not apply to their type of activity.

The study related to the industry awareness of the implemented measures for overcoming 
the pandemic of Covid-19 at local level [22], as well as the effectiveness of their implementation, covers the following measures to address Covid-19 [23]:

- the Municipality of Plovdiv exempts from fees for sidewalk law commercial sites and establishments closed by an order of the Minister of Health during the state of emergency [24];

- traders and tenants of municipal properties that fall within the scope of the order of the Minister of Health to impose a state of emergency will be exempt from rent for the time during which they were closed;

- establishments that rent municipal parking will be exempted from paying it for the time they are not working, as of the time of the state of emergency;

- Plovdiv residents receive a two-month reprieve for payment of the first installment for the garbage fee;

- the term for using a 5\% discount for payment of the entire amount due for building tax and motor vehicle tax has been extended by two months. This discount can be used until June 30 .

Regarding the municipal measures in the city, there is obviously a greater commitment and formed opinion - at the 1-st stage only $13 \%$ are not aware of them, and at the 2-nd stage $18.2 \%$. The last two on the list receive more approval than denial, which is surprising because all five measures aim to alleviate the effects of the crisis. This shows that many people in the sector are already desperate and may not believe in the effectiveness of local government Fig.8 and Fig.9.

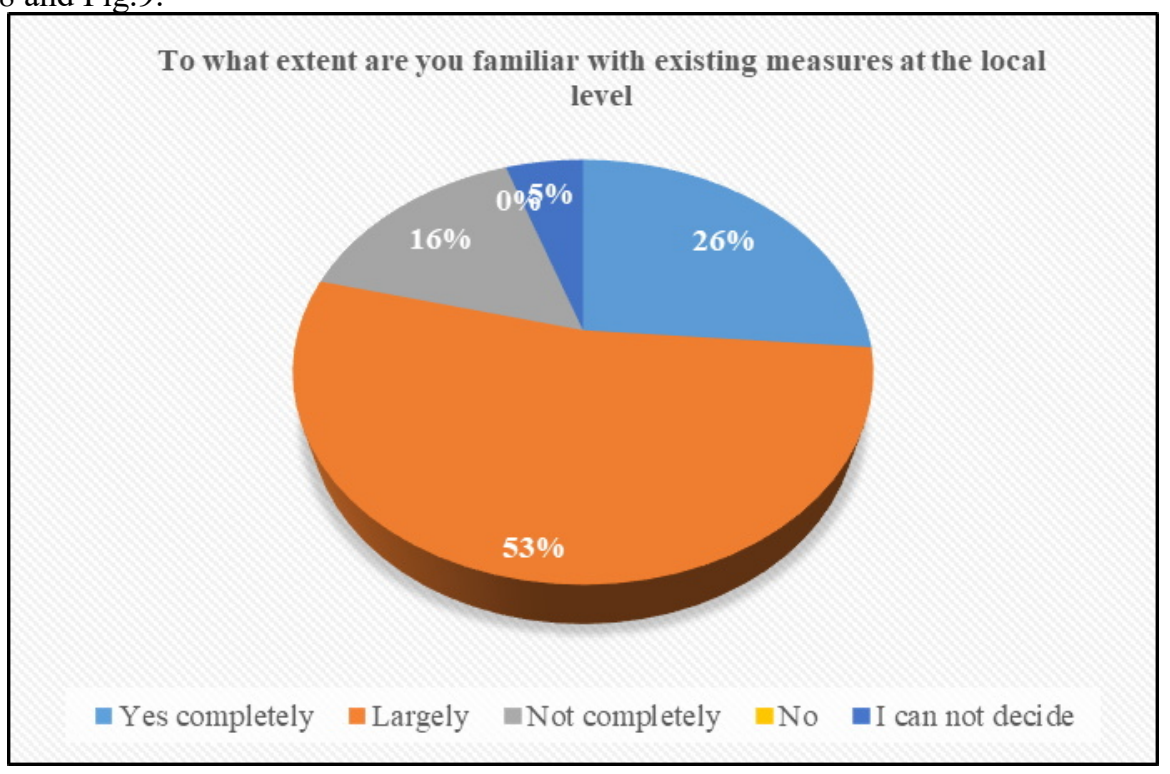

Fig. 8 Level of awareness of measures at the local level 


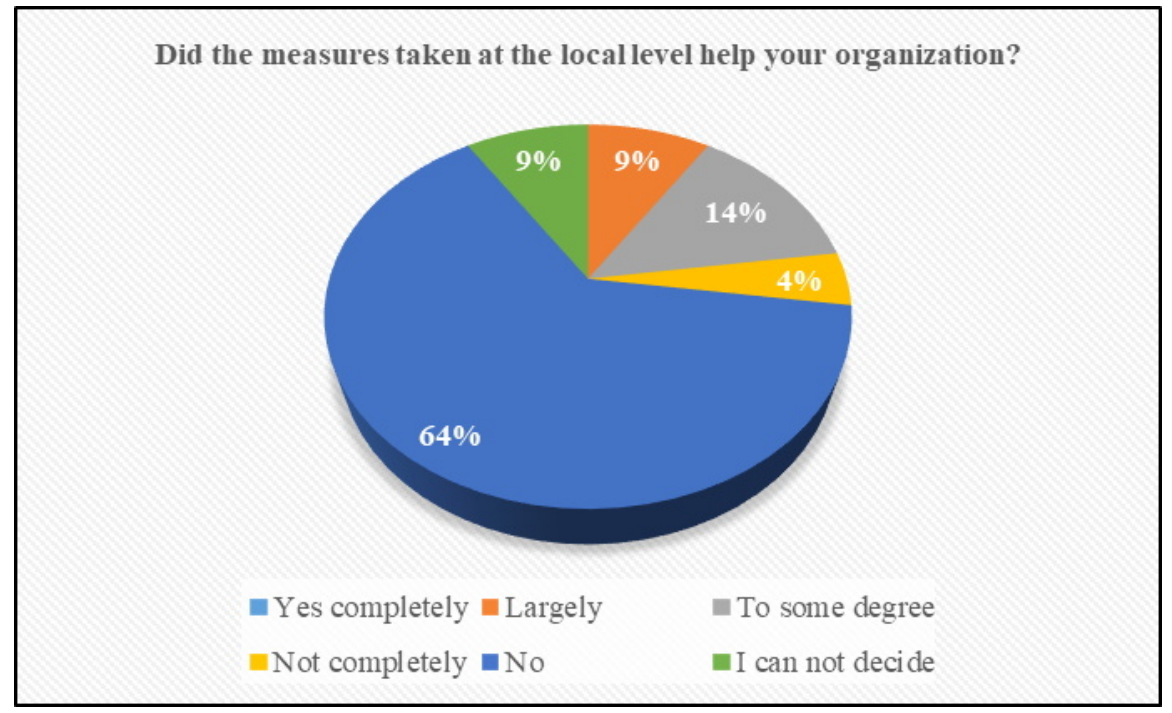

Fig 9. Degree of impact of measures at the local level

C) Future expectations for the development of the sector:

In the expectations for development of the sector after the end of the state of emergency at stage $1,45.1 \%$ of the respondents predicted deterioration of the situation in the Tourism sector, $23.5 \%$ improvement of the situation, $21.6 \%$ return to the situation before the state of emergency, $35.3 \%$ recovery of the sector after 1 year, and $31.6 \%$ that recovery is possible between 6 and 12 months. At stage 2, 68.2\% expect recovery after 2 years and $9.1 \%$ after three.

All the above proofs some positive attitudes of the tourism business in Plovdiv, which in practice means striving for a restart in 2021-2023.

\section{Conclusion}

As a result of the study, the following more important conclusions can be drawn:

- There is a high degree of negative impact of the pandemic on the tourism sector in the city of Plovdiv and the region, with the main part reporting a loss of about $50 \%$ and more, which corresponds to their drastically reduced activity.

- Business organizations have reduced their core business by over $50 \%$, as the free time is redirected to other, additional activities (repair activities, optimization of work processes, creation of new products and services, staff training and others).

- Regarding the measures introduced at the local level, the majority of respondents believe that they were not useful to them or not completely, as they indicate that they are largely familiar with them. The situation is similar in regards to measures at national level.

- Regarding staff, companies have taken measures mainly in discharging unpaid leave, reducing staff and reducing working hours.

- Nearly $2 / 3$ of the participants have the attitude to return to their condition before the crisis, as they believe that it will take 1,2 and more years.

The research team intends to continue its research by monitoring the behavior of participants in the tourism sector related to their economic recovery and the readiness of the industry to restart.

The results of the study can be used to prepare a set of adequate and targeted proposals for economic and social measures to support the tourism industry. The analyzes from the 
survey, with the conclusions and suggestions made, can be presented to state and local administrative institutions to receive feedback on the effectiveness of the developed measures and to take the necessary actions to support the business institutions in the industry.

\section{References}

1. M. Asenova, Covid-krizata v kulturata i turizma, osnovan na kulturno nasledstvo: idei za izhod ot situatsiyata, UI „Sv. K. Ohridski“, ISBN 978-954-07-5215-0, (2021)

2. Survey to the tourism industry in Plovdiv, [Online], https://tourismplovdiv.org/\%d0\%b0\%d0\%bd\%d0\%b0\%d0\%bb\%d0\%b8\%d0\%b7$\% \mathrm{~d} 0 \% \mathrm{bd} \% \mathrm{~d} 0 \% \mathrm{~b} 0-\% \mathrm{~d} 0 \% \mathrm{~b} 0 \% \mathrm{~d} 0 \% \mathrm{bd} \% \mathrm{~d} 0 \% \mathrm{ba} \% \mathrm{~d} 0 \% \mathrm{~b} 5 \% \mathrm{~d} 1 \% 82 \% \mathrm{~d} 0 \% \mathrm{bd} \% \mathrm{~d} 0 \%$ be$\% \mathrm{~d} 0 \% \mathrm{bf} \% \mathrm{~d} 1 \% 80 \% \mathrm{~d} 0 \% \mathrm{be} \% \mathrm{~d} 1 \% 83 \% \mathrm{~d} 1 \% 87 \% \mathrm{~d} 0 \% \mathrm{~b} 2 \% \mathrm{~d} 0 \% \mathrm{~b} 0 \% \mathrm{~d} 0 \% \mathrm{bd} \% \mathrm{~d} 0 \% \mathrm{~b} 5-$ $\% \mathrm{~d} 0 \%$ ba $\% \mathrm{~d} 0 \%$ be $\% \mathrm{~d} 0 \% \mathrm{~b} 5 \% \mathrm{~d} 1 \% 82 \% \mathrm{~d} 0 \%$ be- $\% \mathrm{~d} 0 \% \mathrm{bf} \% \mathrm{~d} 1 \% 80 \% \mathrm{~d} 0 \%$ be $/$

3. A. Pamporov, Parvonachalni efekti ot COVID-19 varhu turizma: tendentsii i vazmozhni merki. Proekt „Predizvikatelstva pred turizma v Bulgaria v konteksta na globalna pandemia ot COVID-19“, IFS-BAN, (2020)

4. Statisticheski danni za mezhdunaroden turizam v Bulgaria za 2020, https://www.tourism.government.bg/bg/kategorii/statisticheski-danni/statisticheskidanni-za-mezhdunaroden-turizum-v-bulgariya-za-2020-g, [Accessed: 11 June 2021]

5. V. Marinov, M. Asenova, Covid-krizata v kulturata i turizma, osnovan na kulturno nasledstvo: idei za izhod ot situatsiyata, UI „Sv. K. Ohridski“, ISBN 978-954-07-52150, 64, (2021)

6. Plovdiv 2019 Foundation, https://plovdiv2019.eu/en/documents, [Accessed: 22 April 2020]

7. Plovdiv 2019 European Cultural Country, https://plovdiv2019.eu/bg/platforms [Accessed: 22 April 2020]

8. Zakon za merkite i deystviyata po vreme na izvanrednoto polozhenie, obyaveno s reshenie na narodnoto sabranie ot 13 mart 2020 i za preodolyavane na posleditsite, https://www.lex.bg/bg/laws/ldoc/2137201253, [Accessed: 07 Dec. 2020]

9. Zapoved na Ministara na turizma ot 17.03.2020 g. za preustanovyavane na organiziranite turisticheski patuvania do 13 april 2020 vklyuchitelno, https://www.tourism.government.bg/bg/kategorii/novini/zapoved-na-ministura-naturizma-nikolinaangelkova-za-preustanovyavane-na [Accessed: 07 Dec. 2020]

10. Ukazania i preporaki na MT i na KZP vav vrazka sas sklyucheni dogovori za turisticheski paketi, chieto izpalnenie e nevazmozhno $\mathrm{v}$ usloviyata na izvanredno polozhenie poradi razprostranenieto na COVID-19 v Bulgaria i po sveta, https://kzp.bg/novini/ukazaniya-i-preporaki-na-ministerstvoto-na-turizma-inakomisiyata-za-zashtita-na-potrebitelite, [Accessed: 07 Dec. 2020]

11. Protseduri-OPIK, https://opic.bg/protseduri-opik/bg16rfop002-2089-podkrepa-zamalki-predpriyatiya-s-oborot-nad-500-000-lv-za-preodolyavane-na-ikonomicheskiteposledstviya-ot-pandemiyata-covid-19

12. Nasoki za kandidatstvane po shemata za predostavyane na bezvazmezdni finansovi sredstva na turoperatori i turisticheski agenti za kompensirane na zagubi v rezultat ot COVID-19, https://www.tourism.government.bg/bg/kategorii/novini/ministerstvotona-turizma-publikuva-nasoki-za-kandidatstvane-po-shemata-za [Accessed: $9 \mathrm{Fev} 2021$ ]

13. BG16RFOP002-2.073 Podkrepa na mikro i malki predpriyatia za preodolyavane na ikonomicheskite posledstvia ot pandemiyata COVID-19, https://opic.bg/public/procedure/bg16rfop002-2073-podkrepa-na-mikro-i-malkipredpriyatiya-za-preodolyavane-na-ikonomicheskite-posledstviya-ot-pandemiyatacovid-19 [Accessed: 09 April 2021] 
14. BG16RFOP002-2.077 Podkrepa za sredni predpriyatia za preodolyavane na ikonomicheskite posledstvia ot pandemiyata COVID-19, https://opic.bg/procedure/bg16rfop002-2077-podkrepa-za-sredni-predpriyatiya-zapreodolyavane-na-ikonomicheskite-posledstviya-ot-pandemiyata-covid-19 [Accessed: 09 April 2021]

15. Employment Agency, https://www.az.government.bg/bg/news/view/zapochva-tretijatetap-na-mjarkata-60-40-3555/ [Accessed: 09 April 2021]

16. Employment Agency, https://www.az.government.bg/pages/zaetost-za-teb/, [Accessed: 09 April 2021]

17. Bulgarian Development Bank, https://bbr.bg/bg/n/pokana-do-tyrgovskite-banki-zauchastie-v-antikrizisnata-programa-za-biznesa/, [Accessed: 09 April 2021]

18. M. Danovski, Finansovi produkti, skroeni za COVID-19, https://www.fmfib.bg/bg/news/149-finansovi-produkti-skroeni-za-covid19 [Accessed: 09 April 2021]

19. FMFIB, https://www.fmfib.bg/bg/news/160-fondat-na-fondovete-oblekchi-usloviyataza-mikrokrediti-za-startirashti-i-sotsialni-predpriyatiya $\% \mathrm{C} 2 \% \mathrm{~A} 0$ [Accessed: 11 April 2021]

20. Covid-19 official information portal, https://coronavirus.bg/bg/merki/ikonomicheski [Accessed: 11 April 2021]

21. National Patient Organization, https://covid.npo.bg/?p=486 [Accessed: 11 April 2021]

22. Official Covid-19 documents of Municipality of Plovdiv, https://www.plovdiv.bg/item/virus/\%D0\%B7\%D0\%B0\%D0\%BF\%D0\%BE\%D0\%B2 $\% \mathrm{D} 0 \% \mathrm{~B} 5 \% \mathrm{D} 0 \% \mathrm{~B} 4 \% \mathrm{D} 0 \% \mathrm{~B} 8 /$

23. Measures of the Municipality of Plovdiv in support of SMEs, https://www.plovdiv.bg/\%D0\%BC\%D0\%B5\%D1\%80\%D0\%BA\%D0\%B8$\% \mathrm{D} 0 \% \mathrm{BD} \% \mathrm{D} 0 \% \mathrm{~B} 0-\% \mathrm{D} 0 \% \mathrm{BE} \% \mathrm{D} 0 \% \mathrm{~B} 1 \% \mathrm{D} 1 \% 89 \% \mathrm{D} 0 \% \mathrm{~B} 8 \% \mathrm{D} 0 \% \mathrm{BD} \% \mathrm{D} 0 \% \mathrm{~B} 0-$ $\% \mathrm{D} 0 \% \mathrm{BF} \% \mathrm{D} 0 \% \mathrm{BB} \% \mathrm{D} 0 \% \mathrm{BE} \% \mathrm{D} 0 \% \mathrm{~B} 2 \% \mathrm{D} 0 \% \mathrm{~B} 4 \% \mathrm{D} 0 \% \mathrm{~B} 8 \% \mathrm{D} 0 \% \mathrm{~B} 2-\% \mathrm{D} 0 \% \mathrm{~B} 2-$ $\% \mathrm{D} 0 \% \mathrm{BF} \% \mathrm{D} 0 \% \mathrm{BE} \% \mathrm{D} 0 \% \mathrm{~B} 4 \% \mathrm{D} 0 \% \mathrm{BA} \% \mathrm{D} 1 \% 80 \% \mathrm{D} 0 \% \mathrm{~B} 5 \% \mathrm{D} 0 \% \mathrm{BF} \% \mathrm{D} 0 \% \mathrm{~B} 0-$ $\% \mathrm{D} 0 \% \mathrm{BD} \% \mathrm{D} 0 \% \mathrm{~B} 0-\% \mathrm{D} 0 \% \mathrm{BC} /$

24. Naredba za opredelyaneto i administriraneto na mestnite taksi i tseni na uslugi na teritoriyata na obshtina Plovdiv, https://plovdiv.obshtini.bg/doc/388893 